\title{
Sensitizing Ewing sarcoma to chemo- and radiotherapy by inhibition of the DNA-repair enzymes DNA protein kinase (DNA-PK) and poly-ADP-ribose polymerase (PARP) $1 / 2$
}

\author{
Britta Vormoor ${ }^{1,2}$, Yvonne T. Schlosser ${ }^{3}$, Helen Blair ${ }^{1}$, Abhishek Sharma ${ }^{4}$, Sarah \\ Wilkinson ${ }^{5}$, David R. Newell ${ }^{6}$ and Nicola Curtin ${ }^{6}$ \\ ${ }^{1}$ Wolfson Childhood Cancer Research Centre, Northern Institute for Cancer Research, Newcastle University, Newcastle upon \\ Tyne, UK \\ ${ }^{2}$ Department of Paediatric and Adolescent Haematology and Oncology, Great North Children's Hospital, Newcastle upon Tyne \\ Hospitals NHS Foundation Trust, Newcastle upon Tyne, UK \\ ${ }^{3}$ German Cancer Research Center, DKFZ, Cell Cycle Control and Carcinogenesis, Heidelberg, Germany \\ ${ }^{4}$ NORLUX Neuro-Oncology Laboratory, Department of Oncology, Luxembourg Institute of Health, Luxembourg, Luxembourg \\ ${ }^{5}$ Northumbria University, Department of Health and Life Sciences, Newcastle upon Tyne, UK \\ ${ }^{6}$ Northern Institute for Cancer Research, Newcastle University, Paul O'Gorman Building, Newcastle upon Tyne, UK \\ Correspondence to: Britta Vormoor, email: britta.vormoor@ncl.ac.uk
}

Keywords: ewing sarcoma, PARP-inhibitor, rucaparib, DNA-PK inhibitor, NU7441

Received: September 07, $2017 \quad$ Accepted: September 16, $2017 \quad$ Published: September 28, 2017

Copyright: Vormoor et al. This is an open-access article distributed under the terms of the Creative Commons Attribution License 3.0 (CC BY 3.0), which permits unrestricted use, distribution, and reproduction in any medium, provided the original author and source are credited.

\section{ABSTRACT}

Background: DNA-PK and PARP inhibitors sensitize cancer cells to chemo- and radiotherapy. ETS transcription factors (EWS-FLI1) have been described as biomarkers for PARP-inhibitor sensitivity. Sensitivity to single agent PARP inhibitors has so far been limited to homologous recombination repair (HRR) deficient tumors, exploiting synthetic lethality.

Results: In clonogenic assays, single agent rucaparib $L_{50}$ values for continuously exposed cells were similar to those observed in HRR-defective cells (CAPAN-1 cell line, BRCA2 defective); however, both ES cell lines (TC-71, CADO-ES1) had functional HRR. In vivo rucaparib administration $(10 \mathrm{mg} / \mathrm{kg}$ daily) showed no responses. In clonogenic assays, rucaparib enhanced temozolomide, camptothecin and radiation cytotoxicity, which was most profound for temozolomide (15-29 fold enhancement). NU7441 increased the cytotoxicity of etoposide, doxorubicin and radiation.

Materials and Methods: We assessed PARP1/2 (rucaparib) and DNA-PK (NU7441) inhibitors in Ewing sarcoma (ES) cell lines by performing growth inhibition and clonogenic assays. HRR was measured by RAD51 focus formation. Single agent rucaparib was assessed in an in vivo orthotopic model.

Conclusions: Single agent rucaparib ES sensitivity in vitro was not replicated in vivo. DNA-PK and PARP inhibitors are good chemo-/radiosensitizers in ES. The future of these inhibitors lies in their combination with chemo-/radiotherapy, which needs to be evaluated in clinical trials.

\section{INTRODUCTION}

The Ewing sarcoma family of tumors (ESFT) is the second most common malignant bone or soft tissue tumor in childhood and adolescence, accounting for approximately $1.5 \%$ of all pediatric cancers. Most patients present with localized disease, but up to $25 \%$ have metastases at presentation [1]. Significant advances have been made over the past decades with 5-year event-free survival (EFS) rates for patients with localized disease increasing up to $70 \%[2,3]$. Despite intensive treatment regimes, survival rates for patients with primary metastatic disease have remained poor with 5-year EFS of 39\% [2], which is reduced to $13 \%$ overall survival in patients 
with relapsed disease [4]. Better treatment strategies for patients with ESFT are thus an urgent clinical need.

One approach to increasing the efficacy of conventional chemo- or radiotherapy lies in its combination with chemo- or radio-sensitizing agents. Commonly used agents in Ewing sarcoma are the topoisomerase II poisons etoposide and doxorubicin, as well as ionizing radiation, which all cause DNA-double strand breaks (DSB). DSB are one of the most cytotoxic forms of DNA damage and if unrepaired may lead to cell death [5]. Homologous recombination repair (HRR) and non-homologous end joining (NHEJ) repair DSB lesions, with NHEJ being the most important repair pathway in the G0 and G1 phase of the cell cycle [6]. The DNA-dependent protein kinase (DNA-PK) is a central component of NHEJ $[7,8]$, and a highly potent and specific inhibitor of DNAPK (NU7441; 2-N-morpholino-8-dibenzothiophenylchromen-4-one) has been used successfully in in vitro and in vivo models to sensitize colon cancer cells and CLL blasts to the effects of DNA-damaging chemo- and/or radiotherapy $[9,10]$.

Many second line treatment regimens also use topoisomerase I poisons (analogs of camptothecin: topotecan and irinotecan) and the DNA-methylating agent temozolomide that induce DNA single strand breaks. To repair the damage these agents inflict, intact DNA base excision repair (BER) and single strand break repair (SSBR) pathways are required. Poly(ADP-ribose) polymerase 1 (PARP1) is an essential element of SSBR. Inhibitors of PARP1 have been shown to increase the antitumor activity of temozolomide and topotecan in preclinical studies, including models of pediatric cancers $[11,12]$. Several PARP inhibitors are in late-stage clinical trial, including combinations with temozolomide and topotecan (reviewed in $[13,14]$ ) and the first study of the combination with temozolomide showed responses in 10/32 patients [15]. However, the most promising clinical utility of PARP inhibitors at present is as single agents in HRR defective tumors, e.g. in BRCA 1 or BRCA 2 defective tumors for which rucaparib recently obtained marketing authorization [16].

Ewing sarcoma (ES) cells are characterized by translocations involving the EWS gene from chromosome 22 and a member of the ETS family of transcription factors, most commonly the FLI1 gene on chromosome 11. Both EWS and EWS-FLI1 proteins interact with BARD1, a putative tumor suppressor, which in turn associates with BRCA1 [17], potentially linking the Ewing sarcoma gene product with HRR. Both PARP1 and DNA-PK interact with EWS-FLI1 [18] and ESFT have high levels of PARP mRNA, protein and polymerase activity [19], and DNAPK catalytic subunit expression (kids cancer kinome database; http://hgserver1.amc.nl/cgi-bin/r2/main.cgi).

In 2012, cells harboring the EWS-FLI1 translocation have been characterized as being particularly sensitive to PARP-inhibition by a high-throughput screening approach
[20], and ES cells and xenografts were sensitive to the PARP-inhibitor olaparib [18]. We wanted to determine whether rucaparib as a single agent is synthetically lethal in ES cells as the EWS-ETS gene product may negatively influence HRR. Additionally we hypothesized that the abundance of PARP and DNA-PKcs implicate a heightened dependence on their activity that might render them particularly sensitive to chemo- and radiosensitization by PARP or DNA-PK inhibitors.

We report here preclinical data showing that the cytotoxicity of single agent rucaparib was time dependent but in vivo experiments failed to demonstrate any measurable effect on tumor growth. The PARPinhibitor, rucaparib, sensitizes ES cells to temozolomide, camptothecin and ionizing radiation and the DNA-PKinhibitor NU7441 sensitizes ES cells to chemo- and radiotherapy. Our data strongly support the evaluation of these compounds in combination with chemo- and/or radio-therapy in in vivo models and clinical trials.

\section{RESULTS}

\section{PARP1}

\section{PARP1 levels and inhibition of PARP1 activity by rucaparib}

PARP1 expression and activity are known to vary widely between cell lines and individuals [21] and this could potentially impact on the response to cytotoxic drugs. We therefore measured PARP1 expression and activity in the ES cells. PARP1 protein was detected in both CADO-ES-1 and TC-71 cells (Figure 1A), with the level of PARP1 in CADO-ES-1 cells being lower than that in TC-71 cells, which in turn was lower than in the reference cell line, K562 (Figure 1A). Despite this difference, both cell lines showed similarly high PARP activity compared to the control cell line L1210 (Figure 1B), and the PARP inhibitor rucaparib at $0.4 \mu \mathrm{M}$ inhibited activity by $>95 \%$ in both cell lines (Figure 1B).

\section{Single agent rucaparib activity}

The impact of rucaparib as a single agent on the survival of TC-71 and CADO-ES1 cells was assessed using clonogenic survival assays. The standard assay consisted of a $24 \mathrm{~h}$ period of drug exposure, followed by harvesting and re-seeding for colony formation in drugfree medium. In the standard assays, the ES cell lines TC71 and CADO-ES1 showed similar sensitivities to single agent rucaparib to that observed in growth inhibition assays, with $\mathrm{LD}_{50}$ values of 5.1 and $8.0 \mu \mathrm{M}$, respectively (Figure 2, left panel for TC-71 cell line). Since the PARP inhibitor cytotoxicity assays in ES reported in the literature $[18,20]$ involved continuous drug exposure for the duration of the experiment, clonogenic assays were also performed with re-drugging of rucaparib 
every 3-5 days. In the experiments involving continuous drug exposure, both cell lines were significantly more sensitive to rucaparib than in our standard $24 \mathrm{~h}$ exposure assays, with $\mathrm{LD}_{50}$ values of $0.5 \mu \mathrm{M}$ for TC-71 cells and $\mathrm{LD}_{50}$ of $1.0 \mu \mathrm{M}$ for CADO-ES1 cells (Figure 2, right panel). HRR competent control cell lines (MCF-7, Hep3B) were less sensitive to rucaparib $\left(\mathrm{LD}_{50}\right.$ of 3 and $10 \mu \mathrm{M}$, respectively). As expected, the HRR defective (BRCA mutant) cell line CAPAN-1 was sensitive towards PARPinhibition, with a $\mathrm{LD}_{50}$ of $1.8 \mu \mathrm{M}$.

Rucaparib exposure for $24 \mathrm{~h}$ without harvesting/reseeding of TC-71 cells resulted in intermediate sensitivity to rucaparib compared to either the standard or continuous exposure clonogenic experiments $\left(\mathrm{LD}_{50} 1.5 \mu \mathrm{M}\right)$ (Figure 2, left panel).

\section{Ewing cells are competent for homologous recombination repair (HRR)}

One possible explanation for the sensitivity of ES cells to rucaparib could lie in the interaction of EWSFLI1 gene products with BARD1 and its association with

A

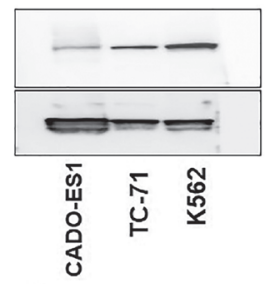

PARP-1 (116 kDa) Actin (44 kDa)

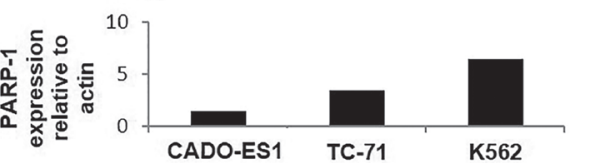

B
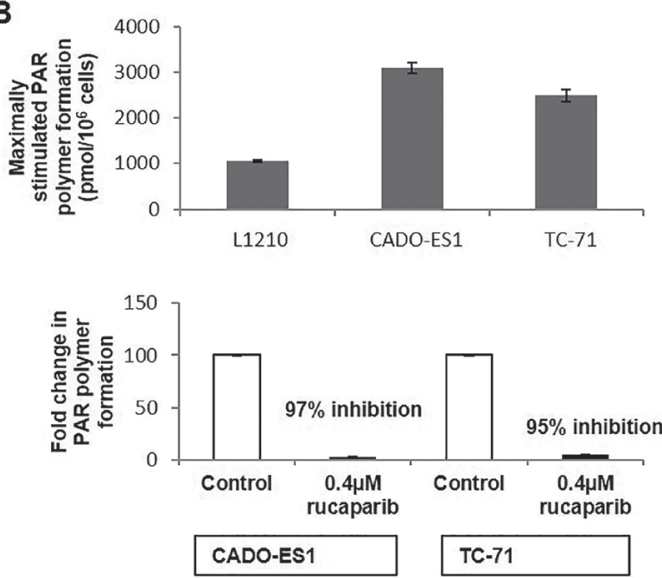

BRCA1 [17], which is essential for functional HRR. The HRR status of the ES cells was therefore explored.

HRR function was determined in TC-71 and CADO-ES1 cells with Hep3B cells as a positive control for functional HRR by measuring $\gamma \mathrm{H} 2 \mathrm{AX}$ and RAD51 focus formation after $24 \mathrm{~h}$ exposure to $10 \mu \mathrm{M}$ rucaparib. All 3 cell lines showed a significant increase in $\gamma \mathrm{H} 2 \mathrm{AX}$ focus formation, indicating the appearance of DSB after inhibition of PARP (Figure 3A). The increase in $\gamma \mathrm{H} 2 \mathrm{AX}$ focus formation was more than 10-fold in both ES cell lines, and about 8-fold in the control cell line Hep3B. Equally, all 3 cell lines showed a strong increase in RAD51 focus formation by at least 10 -fold, thus there is no impairment of HRR in either cell line (Figure 3A, representative microscopy images Figure $3 \mathrm{~B}$ ).

\section{Rucaparib as single agent shows no in vivo activity against TC-71 tumors}

To determine if the cytotoxicity of rucaparib in cell culture experiments translated into an in vivo antitumor effect, immunocompromised mice implanted
C

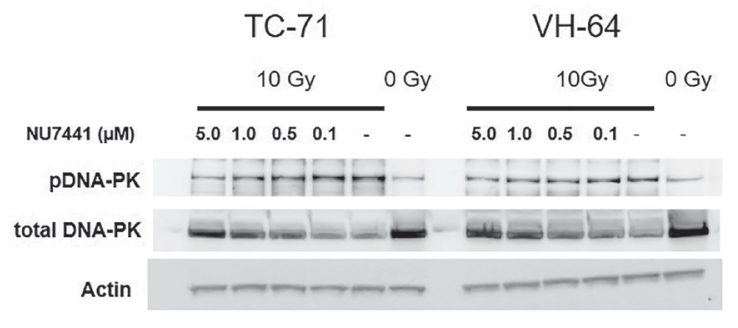

D

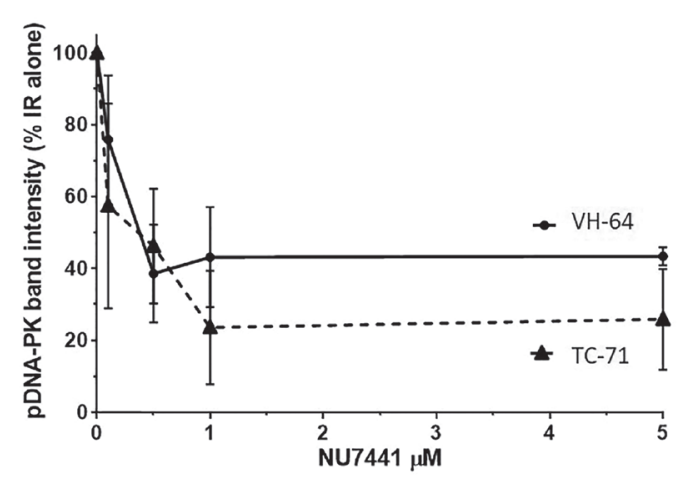

Figure 1: Confirmation of PARP and DNA-PK presence, activity and inhibition by rucaparib or NU7441. (A) Western Blot analysis of PARP1 in Cado-ES1, TC-71 and K562 cells. (B) PARP activity in CADO-ES1, TC-71 and L1210 cells, and its inhibition by $0.4 \mu \mathrm{M}$ rucaparib. (C) Representative Western Blots for total and phosphorylated DNA-PKcs (pDNA-PK) in TC-71 and VH-64 cells (no ionizing radiation and without NU7441: lanes labelled " 0 Gy"), and pDNA-PK signal in response to 10 Gy IR and increasing concentrations of NU7441. (D) Densitometric analysis of pDNA-PK levels: data from 3 separate experiments in TC-71 and VH-64 cells after ionizing radiation with $10 \mathrm{~Gy},+/-\mathrm{NU} 7441$, depicted are mean values +/- SEM. 
intrafemorally with TC-71 cells were treated with rucaparib.

Mice treated with vehicle control $(n=5)$ or single agent rucaparib ( $n=5$, rucaparib $10 \mathrm{mg} / \mathrm{kg}$ daily on $5 / 7$ days for 6 weeks or until the end point for experiment was reached) demonstrated comparable tumor growth characteristics, without any evidence of tumor responses (Figure 4A, 4B). There was no significant clinical toxicity of single agent rucaparib at this dose.

Weight changes of individual mice ranged between $-9.5 \%$ to $+2 \%$ total body weight for control animals, compared to $-7.4 \%$ to $-0.3 \%$ for rucaparib treated animals (data not shown).

\section{Growth inhibition assays using rucaparib}

Rucaparib on its own did not cause any significant growth inhibition at $0.4 \mu \mathrm{M}$; the mean rucaparib $\mathrm{GI}_{50}$ concentration for TC-71 cells was $5.0 \mu \mathrm{M}$ and for CADOES1 cells $4.7 \mu \mathrm{M}$, i.e. similar or slightly less sensitive than the confirmed HRR-competent MCF7 cell line $\left(\mathrm{GI}_{50}\right.$ $2.4 \mu \mathrm{M})$ (Supplementary Figure 1).

TC-71 and CADO-ES1 cells were equisensitive to camptothecin $\left(\mathrm{GI}_{50}: 3\right.$ and $\left.2 \mathrm{nM}\right)$, ionizing radiation $\left(\mathrm{GI}_{50}: 2.2\right.$ and $\left.1.8 \mathrm{~Gy}\right)$ and temozolomide $\left(\mathrm{GI}_{50}: 0.3\right.$ and $0.25 \mathrm{mM})$, respectively. Rucaparib at a concentration of $0.4 \mu \mathrm{M}$ enhanced the cytotoxicity of temozolomide between 5- to 10-fold, of camptothecin 1.4- to 2-fold and ionizing radiation 1.4 fold (Supplementary Figure 2).

\section{Cytotoxicity assays using rucaparib}

\section{Chemo-/radio-potentiation}

To determine if the reduced cell numbers observed in growth inhibition assays was due to cytotoxicity rather than mere cytostasis, we performed colony formation (clonogenic) assays.

Both TC-71 and CADO-ES1 cells were approximately equally sensitive to temozolomide with

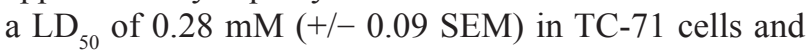
$0.33 \mathrm{mM}(+/-0.07 \mathrm{SEM})$ in CADO-ES1 cells. Rucaparib at a non-toxic concentration of $0.4 \mu \mathrm{M}$ caused a very profound sensitization in both cell lines, with a 29 -fold $\left(+/-9\right.$ SEM) sensitization in TC-71 cells (mean $\mathrm{LD}_{50}: 0.01$ $\mathrm{mM})$ and a 15 -fold (+/- 3 SEM) sensitization in CADOES1 cells (mean $\mathrm{LD}_{50}: 0.02 \mathrm{mM}$ ), all results being highly statistically significant (2-way ANOVA: $p<0.0001$ ) (Table 1; Figure 5B).

Both cell lines displayed similar sensitivities to camptothecin, with a mean $\mathrm{LD}_{50}$ of $5.5 \mathrm{nM}$ in TC-71 cells and $6.0 \mathrm{nM}$ in CADO-ES1 cells. Rucaparib caused a 1.4fold potentiation $\left(\mathrm{LD}_{50}=4.1 \mathrm{nM}\right)$ in TC-71 cells and a 2-fold potentiation $\left(\mathrm{LD}_{50}=2.9 \mathrm{nM}\right)$ in CADO-ES1 cells, but these effects were not, or marginally, statistically significant ( $p=0.2$ and 0.02 ).

The two cell lines were equally sensitive to ionizing radiation, with $\mathrm{LD}_{50}$ values of $1.1 \mathrm{~Gy}$ for both $\mathrm{TC}$ 71 and CADO-ES1 cells. Rucaparib caused a modest radiosensitization of 1.7 -fold in TC-71 cells (mean $\mathrm{LD}_{50} 0.7 \mathrm{~Gy} ; p=0.002$ ) and of 1.4-fold in CADO-ES1 cells (mean $\mathrm{LD}_{50} 0.7 \mathrm{~Gy}, p=0.08$ ). All of the rucaparib combination data are summarized in Table 1.

\section{DNA-PK}

\section{DNA-PKes as a determinant of the effects of cytotoxic treatment}

To determine which classes of cytotoxic drugs are dependent on DNA-PK activity for repair of the damage they inflict, we performed experiments with
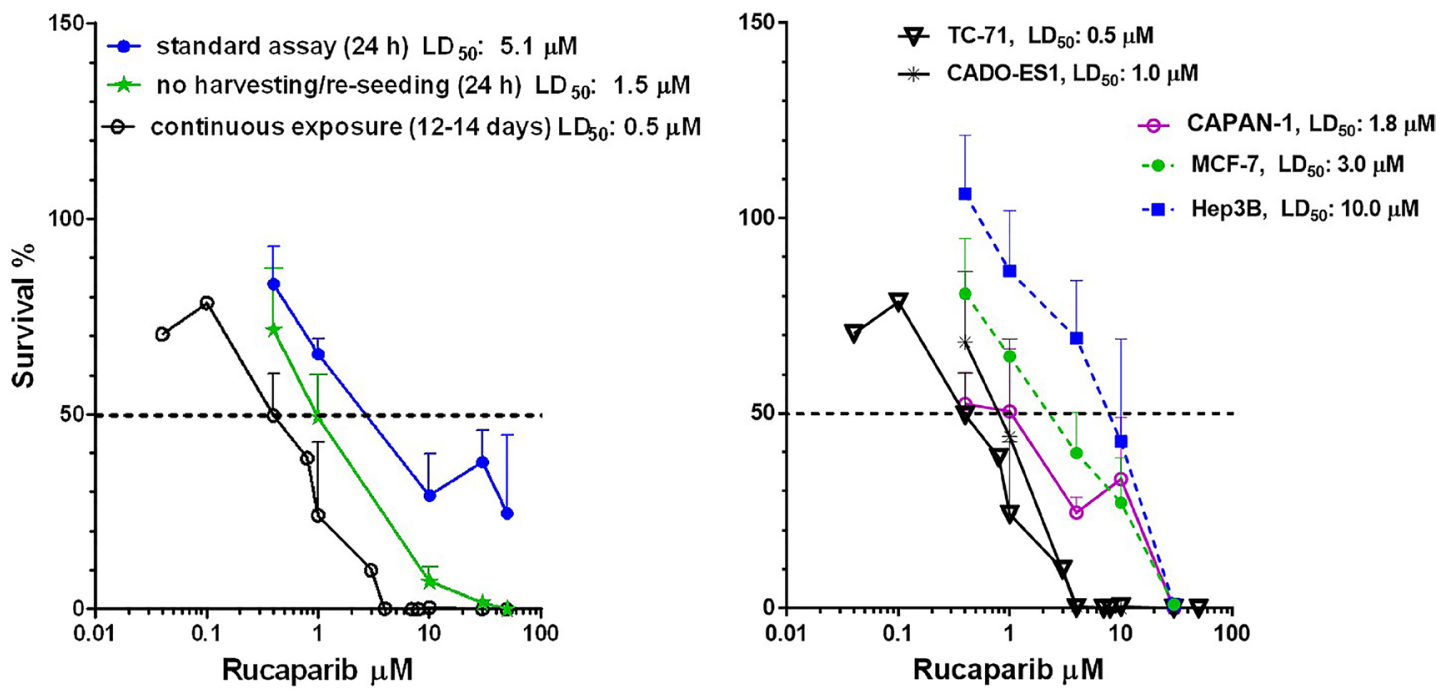

Figure 2: The effect of drug exposure time in clonogenic assays. (A) Comparison of continuous exposure (12-14 days) to other clonogenic assays ( $24 \mathrm{~h}$ drug exposure with and without harvesting/reseeding) in TC-71 cells. (B) Clonogenic assays (continuous exposure) for rucaparib cytotoxicity in 5 different cell lines. 
Table 1: Summary of clonogenic assay results

\begin{tabular}{|c|c|c|c|c|c|}
\hline Cell line & Treatment & $\begin{array}{c}\text { Clonogenic } \\
\text { assays } \\
\text { performed } \\
(n)\end{array}$ & $\begin{array}{l}\text { Mean LD } \\
\text { (+/-SEM) }\end{array}$ & $\begin{array}{l}\text { Mean DRF }_{50} \\
(+/- \text { SEM) }\end{array}$ & 2-way ANOVA \\
\hline \multirow[t]{3}{*}{ VH-64 } & $\begin{array}{l}\text { Doxorubicin } \\
\text { Doxorubicin + NU7441 }\end{array}$ & 4 & $\begin{array}{l}12.2 \mathrm{nM}(1.3) \\
5.5 \mathrm{nM}(0.26)\end{array}$ & $2.2(0.2)$ & $P<0.0001$ \\
\hline & $\begin{array}{l}\text { Etoposide } \\
\text { Etoposide + NU7441 }\end{array}$ & 3 & $\begin{array}{l}0.10 \mu \mathrm{M}(0.01) \\
0.04 \mu \mathrm{M}(0.01)\end{array}$ & $2.7(0.4)$ & $P<0.0001$ \\
\hline & $\begin{array}{l}\text { IR } \\
\text { IR + NU7441 }\end{array}$ & 3 & $\begin{array}{l}0.99 \text { Gy }(0.24) \\
0.36 \text { Gy }(0.02)\end{array}$ & $2.8(0.7)$ & $P<0.0001$ \\
\hline \multirow[t]{6}{*}{ TC-71 } & $\begin{array}{l}\text { Doxorubicin } \\
\text { Doxorubicin }+ \text { NU7441 }\end{array}$ & 3 & $\begin{array}{c}13.4 \mathrm{nM}(2.3) \\
6.3 \mathrm{nM}(0.6)\end{array}$ & $2.1(0.2)$ & $P=0.0008$ \\
\hline & $\begin{array}{l}\text { Etoposide } \\
\text { Etoposide + NU7441 }\end{array}$ & 3 & $\begin{array}{l}0.28 \mu \mathrm{M}(0.05) \\
0.04 \mu \mathrm{M}(0.01)\end{array}$ & $6.7(0.8)$ & $P<0.0001$ \\
\hline & $\begin{array}{l}\text { IR } \\
\text { IR + NU7441 }\end{array}$ & 3 & $\begin{array}{l}1.32 \mathrm{~Gy}(0.07) \\
0.39 \mathrm{~Gy}(0.02)\end{array}$ & $3.4(0.2)$ & $P<0.0001$ \\
\hline & $\begin{array}{l}\text { Temozolomide } \\
\text { Temozolomide }+ \text { rucaparib }\end{array}$ & 3 & $\begin{array}{l}0.28(0.09) \\
0.01(0.00)\end{array}$ & $29(9)$ & $P<0.0001$ \\
\hline & $\begin{array}{l}\text { Camptothecin } \\
\text { Camptothecin }+ \text { rucaparib }\end{array}$ & 3 & $\begin{array}{l}5.5 \mathrm{nM}(0.6) \\
4.1 \mathrm{nM}(0.8)\end{array}$ & $1.4(0.3)$ & $P=0.2$ \\
\hline & $\begin{array}{l}\text { Ionizing radiation } \\
\text { Ionizing radiation + rucaparib }\end{array}$ & 4 & $\begin{array}{l}1.08 \mathrm{~Gy}(0.24) \\
0.68 \mathrm{~Gy}(0.07)\end{array}$ & $1.7(0.4)$ & $P=0.002$ \\
\hline \multirow[t]{3}{*}{ CADO-ES1 } & $\begin{array}{l}\text { Temozolomide } \\
\text { Temozolomide +rucaparib }\end{array}$ & 3 & $\begin{array}{c}0.33 \mathrm{mM}(0.07) \\
0.02 \mathrm{mM}(0.003)\end{array}$ & $15(3)$ & $P<0.0001$ \\
\hline & $\begin{array}{l}\text { Camptothecin } \\
\text { Camptothecin }+ \text { rucaparib }\end{array}$ & 2 & $\begin{array}{l}6.0 \mathrm{nM}(1.3) \\
2.9 \mathrm{nM}(0.3)\end{array}$ & $2.0(0.2)$ & $P=0.02$ \\
\hline & $\begin{array}{l}\text { Ionizing radiation } \\
\text { Ionizing radiation }+ \text { rucaparib }\end{array}$ & 3 & $\begin{array}{l}1.06 \text { Gy }(0.47) \\
0.74 \text { Gy }(0.31)\end{array}$ & $1.4(0.1)$ & $P=0.08$ \\
\hline
\end{tabular}

$\mathrm{LD}_{50}$ : concentration of drug necessary to inhibit colony formation by $50 \%$. SEM $=$ Standard Error of Mean. $\mathrm{DRF}=$ dose reduction factor, calculated by dividing the $\mathrm{LD}_{50}$ results for the cells treated with cytotoxic alone and those of the corresponding cells treated with cytotoxic plus inhibitor.

Summary of all clonogenic assays in Ewing sarcoma cell lines evaluated for combinations of NU7441 (1.0 $\mu \mathrm{M})$ or rucaparib $(0.4 \mu \mathrm{M})$ with chemotherapeutic agents or ionizing radiation.

DNA-PKcs deficient V3 cells, and their DNA-PKcs complemented derivative cell line V3-YAC, in which the gene for the human DNA-PKcs had been reintroduced via a yeast artificial chromosome (YAC). In clonogenic assays comparing the 2 cell lines, the $\mathrm{LD}_{50}$ values for topoisomerase II poisons (etoposide and doxorubicin), and $\mathrm{LD}_{50}$ values for ionizing radiation were significantly lower for the V3 (DNA-PKcs deficient) cells compared to the DNA-PKcs proficient V3-YAC cells, with dose reduction factors (DRF) between 2.4-2.9 (Supplementary Figure 3). In contrast, the alkylating agent 4-hydroperoxycyclophosphamide, the topoisomerase I poison topotecan and the platinum drug cisplatin did not show any significant differences in their $\mathrm{LD}_{50}$ values (Supplementary Figure 3). Temozolomide was slightly more cytotoxic in DNA-PK deficient V3 cells, but the DRF was only 1.6.
For these reasons, chemopotentiation by NU7441 of doxorubicin and etoposide only was investigated further.

\section{Inhibition of DNA-PKes by NU7441}

Since DNA-PKcs expression and activity could potentially impact on drug- and radiosensitivity, these parameters were assessed by Western Blot. TC-71 and VH-64 had similar levels of DNA-PKcs protein (total DNA-PK) (Figure 1C). After DSB induction by ionizing radiation (10 Gy), there was a strong increase in signal intensity of phosphorylated DNA-PK at serine2056; a marker for DNA-PK activation. In both cell lines, cotreatment of the cells with NU7441 revealed inhibition of DNA-PK activity in a concentration dependent manner, with a maximal inhibition at $1.0 \mu \mathrm{M}$ NU7441 in both 
cell lines (Figure 1D). All subsequent experiments were performed in the presence of $1.0 \mu \mathrm{M}$ NU7441.

\section{Chemo- and radio-potentiation using the DNA- PK inhibitor NU7441}

Using standard clonogenic assays on TC-71 and VH-64 cells, NU7441 alone was not toxic at $1.0 \mu \mathrm{M}$. In TC-71 cells, the NU7441 $\mathrm{LD}_{50}$ was $12 \mu \mathrm{M}(n=5$ clonogenic assays, Figure 5A, left panel), and in VH-64 cells the $\mathrm{LD}_{50}$ was $16 \mu \mathrm{M}$ ( $n=1$ clonogenic assay).

As predicted from the data presented in Supplementary Figure 3, NU7441 markedly potentiated the cytotoxicity of doxorubicin, etoposide and ionizing radiation when used at $1 \mu \mathrm{M}$ (Figure 5A). NU7441 enhanced the cytotoxicity of doxorubicin 2-fold at the $\mathrm{LD}_{50}$ concentration (doxorubicin alone: $\mathrm{LD}_{50}=12-13 \mathrm{nM}$; doxorubicin with $1 \mu \mathrm{M}$ NU7441 $\mathrm{LD}_{50}=6 \mathrm{nM}$ ), and for both cell lines this effect was highly significant (2-way ANOVA $p=0.0008$ for TC-71, $p<0.0001$ for VH-64 cells). Potentiation of etoposide cytotoxicity by NU7441 was even greater (3-7 fold), with $\mathrm{LD}_{50}$ values for etoposide alone being $0.1 \mu \mathrm{M}$ in $\mathrm{VH}-64$ and $0.28 \mu \mathrm{M}$ in $\mathrm{TC}-71$ cells, reduced to $0.04 \mu \mathrm{M}$ by NU7441, the effect again being highly significant in both cell lines (2-way ANOVA $p<0.0001)$. In addition, NU7441 potentiated the effects of ionizing radiation in both cell lines, causing a 3 -fold reduction in cell survival (ionizing radiation alone $\mathrm{LD}_{50}$ $=1.0-1.3 \mathrm{~Gy}$, ionizing radiation in presence of NU7441 $\mathrm{LD}_{50}=0.36-0.4 \mathrm{~Gy} ; 2$-way ANOVA $\left.p<0.0001\right)$. All of the NU7441 combination data are summarized in Table 1.

\section{DISCUSSION}

Dysregulation of the DNA damage response has emerged over the past decade as both a contributor to

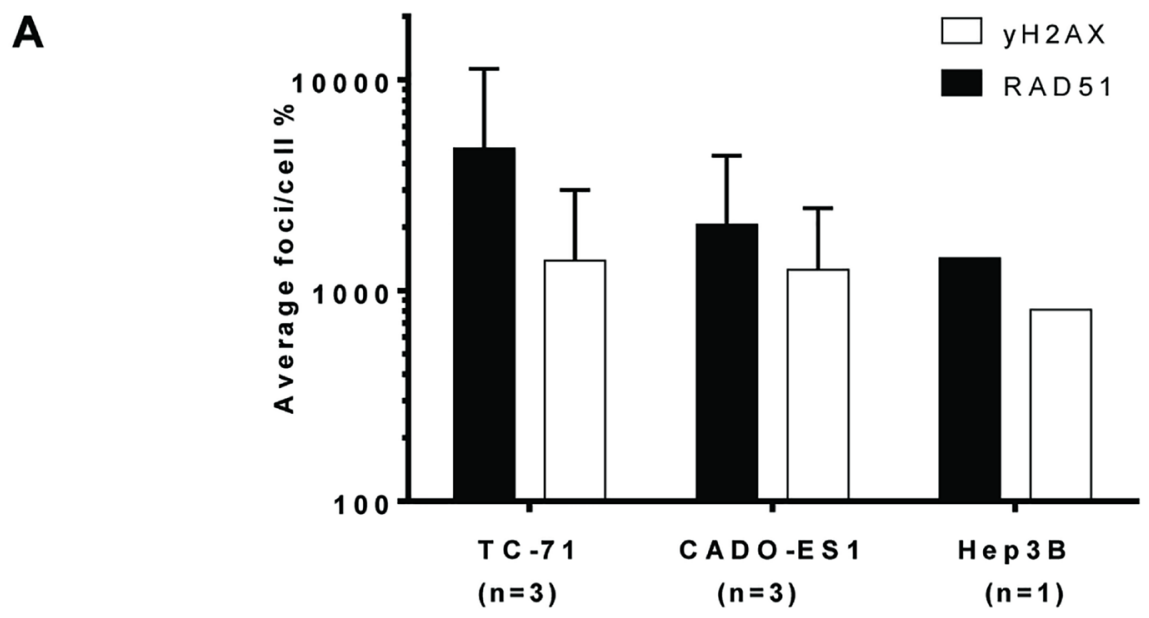

B
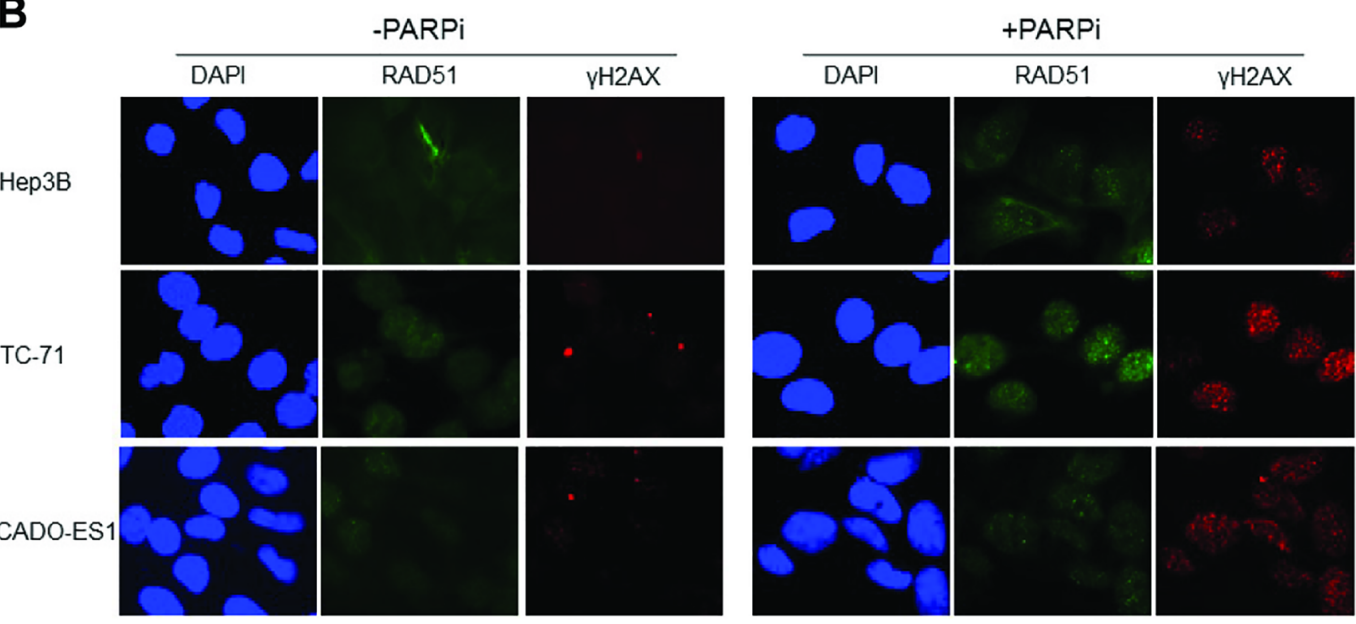

Figure 3: The Ewing sarcoma cell lines TC-71 and CADO-ES1 are competent for homologous recombination repair. (A) Increase of $\gamma \mathrm{H} 2 \mathrm{AX}$ and rad51 foci after $24 \mathrm{~h}$ exposure to $10 \mu \mathrm{M}$ rucaparib, relative to untreated control cells (100\%), data for TC-71 and CADO-ES1 cells with the mean $+/-$ SD of 3 repeated experiments. (B) Representative microscopy images for data shown in 3A. 
genomic instability and thus carcinogenesis, but also as a possible therapeutic opportunity, either for overcoming drug resistance or for exploiting synthetic lethality [6]. This study evaluated inhibitors of two different DNA repair pathways, i.e. base excision repair (BER)/single strand break repair (SSBR) and non homologous end joining (NHEJ), representing the pathways responsible for DNA single and double strand break repair. Ewing sarcoma was investigated as there is an urgent clinical need to improve treatment outcomes in inoperable, metastatic and relapsed patients. Pilot data in DNA-PKcs deficient and proficient cells demonstrated that sensitivity to both ionizing radiation and drugs commonly used in treatment strategies for Ewing sarcoma (doxorubicin, etoposide) was greater in the DNA-PKcs deficient cells (Supplementary Figure 1)
Inhibitors of DNA-PKes have been used in vitro in colon cancer models and CLL blasts to enhance sensitivity to radio- and chemo-therapeutic treatments $[9,10]$, but pediatric malignancies so far have not been studied. The inhibitor NU7441 has improved potency and specificity over its predecessors NU7026 and LY294002, with an $\mathrm{IC}_{50}$ of $14 \mathrm{nM}$ and $\mathrm{a}>100$ fold specificity for DNA-PK over other PI3 kinase family members [22]. The expression and activity of DNA-PKcs was confirmed in ES cell lines, and concentration dependent inhibition by NU7441 was demonstrated. In in vitro assays, NU7441 was shown to sensitize ES cells to etoposide, doxorubicin and ionizing radiation with $\mathrm{DRF}_{50}$ values of 2.7-6.7, 2.1-2.2 and 2.8-3.4, respectively, all combinations being significantly different to the respective DNA-damaging agent alone in 2-sided ANOVA analyses. These are encouraging results that

A

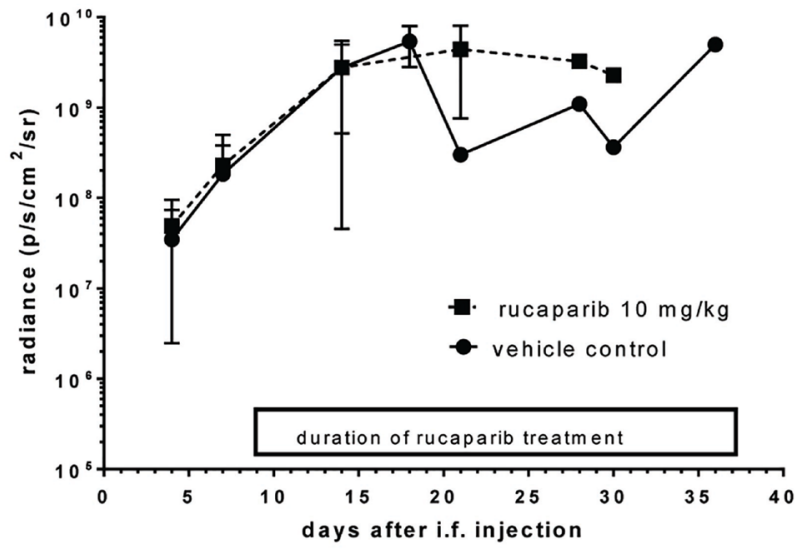

B

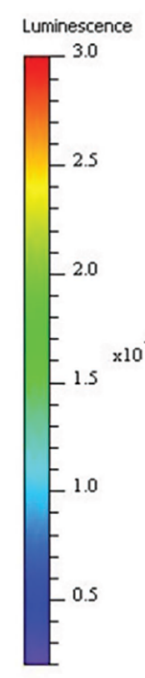

Radiance (p/sec/cm²/sr)

Color Scale Min $=2.00 e 6$
Max $=3.00 \mathrm{e} 7$
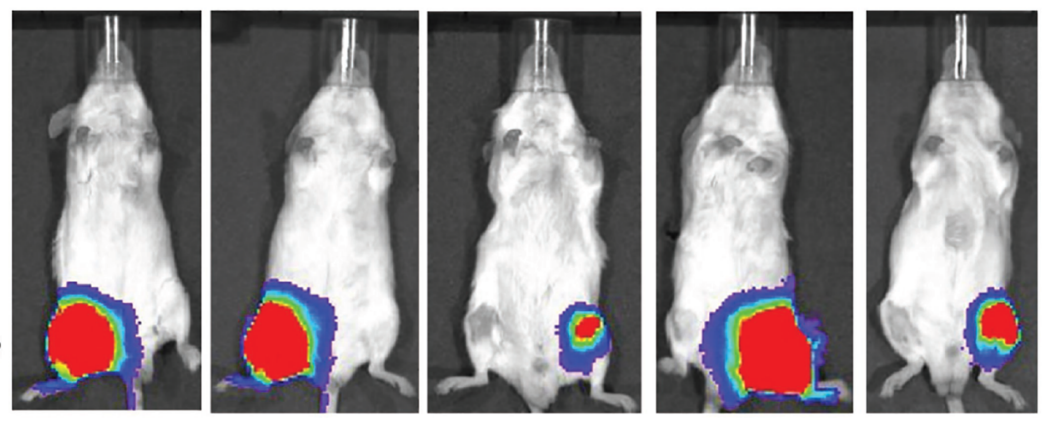

vehicle control
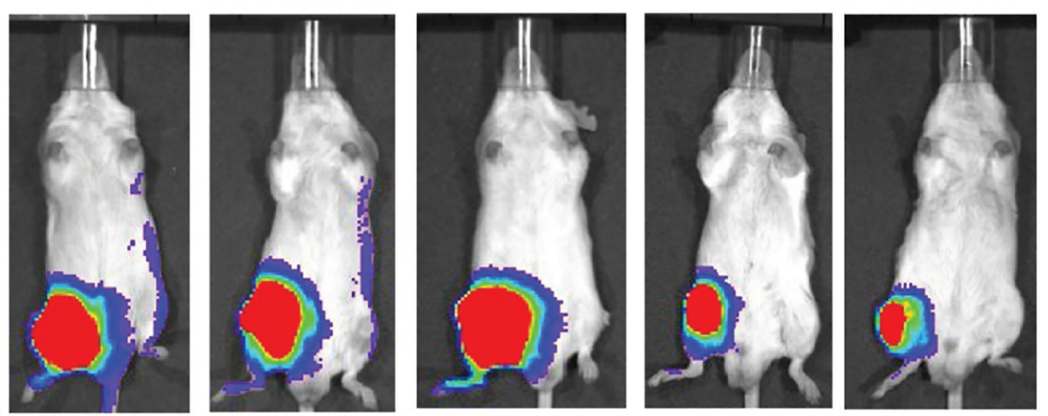

rucaparib

Figure 4: Results of single agent rucaparib in an orthotopic mouse model with TC-71 derived tumors. (A) TC-71 tumor growth as measured by radiance $\left(\mathrm{p} / \mathrm{s} / \mathrm{cm}^{2} / \mathrm{sr}\right)$. (B) Final bioluminescent imaging of each mouse on the respective day of culling. 
warrant further investigations in in vivo models. There are currently two DNA-PK inhibitors (MSC2490484A: DNAPK inhibitor, trials NCT02316197 and NCT02516813; CC-115: dual DNA-PK and TOR kinase inhibitor, trial NCT01353625) undergoing testing in Phase I clinical trials in adult patients, including those with Ewing sarcoma, as single agents and for MSC2490484A also as a radio-/ chemo-sensitizing agent.

PARP inhibition as an approach to the treatment of Ewing sarcoma has attracted increasing attention over the past years, after the publication by Garnett and colleagues identified the translocation EWS-FLI1 as a biomarker for PARP inhibitor sensitivity, and Brenner et al. reported that EWS-FLI1 interacts with PARP1 and influences its transcriptional activity. In other cancers, for example BRCA-deficient breast or ovarian cancer, sensitivity to PARP inhibition is due to defects in HRR, resulting in synthetic lethality. As EWS-FLI1 is reported to interact with BARD1, which associates with BRCA1, the HRR status of the ES cells was evaluated. Fluorescent microscopy assays for $\gamma \mathrm{H} 2 \mathrm{AX}$ and RAD51 foci clearly demonstrated that both ES cell lines were competent for HRR.
Evaluation of the PARP1 inhibitor rucaparib in the two ES cell lines confirmed previous publications by Brenner and Garnett that ES cells are sensitive to single agent PARP1 inhibitors. However, in vitro sensitivity was strongly influenced by the type of assay used, i.e. there was a 10 -fold difference in $\mathrm{LD}_{50}$ depending on the duration of exposure to rucaparib (24 h standard assay versus continuous exposure). In our in vivo experiments, mice were treated with single agent rucaparib at the dose of $10 \mathrm{mg} / \mathrm{kg}$ i.p. daily for 5 days/week for the duration of the experiment. This dose and schedule previously led to delayed tumor growth in various BRCA deficient in vivo models [23] but did not show any measurable effect on ES tumor growth. Despite the dose used in mice being well below the RP2D for rucaparib monotherapy in ovarian cancer $\left(600 \mathrm{mg}\right.$, resulting in a $\mathrm{C}_{\max }$ of 6 $\mu \mathrm{M} / 1$, equivalent to $100 \mathrm{mg} / \mathrm{kg}$ in mice $[24,25]$ ), this result however confirms in vivo studies of other PARP inhibitors (BMN673, olaparib) performed by Norris and by Smith from the Pediatric Preclinical Testing Program, who also failed to show any significant responses or survival benefit by single agent PARP inhibitors [26, 27].
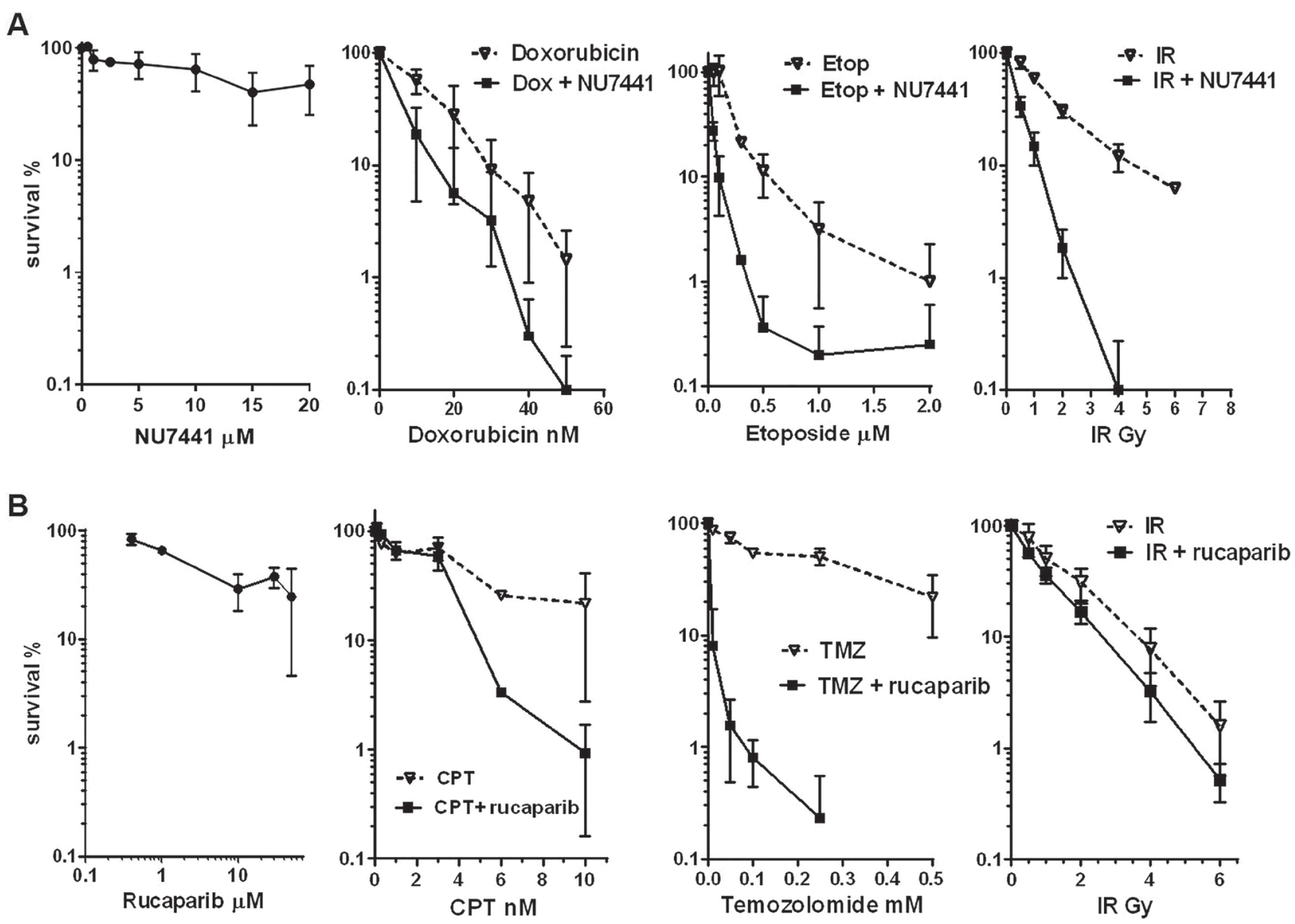

Figure 5: Representative graphs of clonogenic assays in TC-71 cells using NU7441 or rucaparib. (A) Representative clonogenic assays with NU7441 alone ( $24 \mathrm{~h}$ standard exposure) and $1.0 \mu \mathrm{M}$ NU7441 in combination with doxorubicin, etoposide or ionizing radiation (IR). Points, mean of triplicate samples from three independent experiments; bars, SD. (B) Representative clonogenic assays with rucaparib alone ( $24 \mathrm{~h}$ standard exposure) and $0.4 \mu \mathrm{M}$ rucaparib in combination with ionizing radiation, temozolomide and camptothecin. Points, mean of triplicate samples from three or four independent experiments; bars, SD. 
Furthermore, a Phase II clinical trial with olaparib in patients with recurred/progressive ESFT did not report any clinical responses [28]. It is therefore likely that other, as yet unknown, factors render Ewing sarcoma tumors insensitive to single agent PARP inhibition in vivo.

In combination with DNA-damaging agents, rucaparib was able to sensitize ES cells to the effects of temozolomide, camptothecin and ionizing radiation, with the chemo-potentiation of temozolomide being the most profound (mean $\mathrm{DRF}_{50}$ 15-29). These results are in line with other published findings on chemo- and radio-potentiation both in vitro and in vivo ([29] and reviewed in [14]). Combinations of PARP inhibitors with chemotherapy (temozolomide or irinotecan, or both) in patients to date are still ongoing (e.g. NCT01858168, NCT02392793); however, systemic toxicity, especially myelosuppression, is anticipated.

Radio-potentiation via PARP- or alternatively DNAPK-inhibition potentially bears valuable clinical benefit, as it would lack systemic toxicity and could improve the outcome for inoperable, large or axial Ewing sarcomas. Lee et al. have recently published results on radiopotentiation of ES cell lines by olaparib, both in vitro and using an in vivo preclinical model, with very encouraging results [30].

In summary, targeting DNA-repair pathways in combination with DNA-damaging agents is a promising approach to improving treatment strategies for Ewing sarcoma. Whereas inhibition of NHEJ by targeting DNAPKcs needs further preclinical investigation in vivo, PARP inhibitors as chemo-sensitizers for temozolomide and irinotecan are already being investigated in clinical trials for Ewing sarcoma and other cancers. Results of these trials are eagerly awaited, and ionizing radiation also needs to be investigated in combination with these PARP inhibitors, for the benefit of patients with metastatic, inoperable or relapsed Ewing sarcoma.

\section{MATERIALS AND METHODS}

\section{Chemicals}

Temozolomide was a gift from Cancer Research UK, London, United Kingdom. Doxorubicin, etoposide and camptothecin were purchased from Sigma Aldrich, UK. The DNA-PK inhibitor NU7441 was synthesized at the Northern Institute for Cancer Research as described previously [22] and dissolved at $2 \mathrm{mM}$ in DMSO. The PARP-inhibitor rucaparib (formerly AG014699) was a gift from Clovis Oncology, Inc. (Boulder, CO, USA) and dissolved in $10 \mathrm{mM}$ DMSO.

\section{Cell lines and culture}

The Chinese hamster ovary cell line V3 (deficient for DNA-PKcs) and its derivative cell line V3-YAC (transfected with the human gene for DNA-PKcs via a yeast artificial chromosome (YAC)) were a gift from Dr P. Jeggo (University of Sussex, UK).

The ES cell lines TC-71 [31] and VH-64 [32] with the typical translocation $\mathrm{t}(11 ; 22)(\mathrm{q} 24 ; \mathrm{q} 12)$ resulting in the EWS/FLI-1 fusion transcript [33] were obtained as a gift from the department of pediatric hematology/oncology (Prof H. Jürgens University Hospital Münster, Germany). CADO-ES-1 cells [34] carrying the translocation $\mathrm{t}(21 ; 22)$ (q22;q12) and leading to an EWS/ERG fusion transcript [35] were purchased from DSMZ (Germany). V3, V3-YAC and all ES cell lines were cultured in RPMI 1640 medium (Sigma-Aldrich, UK) containing 10\% (v/v) fetal bovine serum (FBS), penicillin $(100 \mathrm{U} / \mathrm{ml})$ and streptomycin $(0.1$ $\mathrm{mg} / \mathrm{ml}$ ) at $37^{\circ} \mathrm{C}$ in a humidified atmosphere with $5 \% \mathrm{CO}_{2}$ in air. The medium for ES cells contained additional $2 \mathrm{mM}$ L-glutamine. V3-YAC cells were cultured in the presence of the antibiotic G-418 sulfate $(500 \mu \mathrm{g} / \mathrm{ml}$, Invitrogen, California, USA) to retain the YAC.

The human BRCA2 defective pancreatic carcinoma cell line CAPAN-1 was obtained from ATCC (Manassas, VA, USA) and maintained in RPMI 1640 medium with $15 \%(v / v)$ FBS [36]. The human breast cancer cell line MCF-7 and the hepatocellular carcinoma cell line Hep3B were obtained from the ATCC (Manassas, VA, USA), and both are HRR competent $[23,37]$. MCF-7 cells were grown in the same medium as the ES cell lines, but without additional glutamine. Hep3B cells were cultured in DMEM/Ham's F12 supplemented with 10\% (v/v) FBS, 2 $\mathrm{mM}$ L-glutamine, penicillin $(100 \mathrm{U} / \mathrm{ml})$ and streptomycin $(0.1 \mathrm{mg} / \mathrm{ml})$. All cell lines were regularly confirmed mycoplasma free (MycoAlert ${ }^{\mathrm{TM}}$, Lonza) and used up to the 30th passage. Capan-1, Hep3B, MCF-7, VH-64 and TC-71 cells were authenticated by short tandem repeat profiling (LGC Standards) during the experimental work. All flasks and dishes intended for growing ES cells were collagen coated. For collagen coating, dishes were covered with a solution of rat tail collagen type I (BD Biosciences, $0.2 \mathrm{mg} / \mathrm{ml}$ in $0.1 \mathrm{M}$ glacial acetic acid) and allowed to dry overnight in a tissue culture hood.

\section{Growth inhibition assays}

Cell growth inhibition assays of exponentially growing TC-71, CADO-ES-1 and MCF-7 cells were performed in 6-well plates. Cells were seeded at a density of $1 \times 10^{4}$ cells per well to ensure exponential growth for the duration of the assay. Twenty-four hours post seeding, cells were exposed to medium containing varying concentrations of temozolomide or camptothecin, in the presence or absence of $0.4 \mu \mathrm{M}$ rucaparib in a final concentration of $0.5 \%(\mathrm{v} / \mathrm{v})$ DMSO. The concentration of $0.4 \mu \mathrm{M}$ was chosen as it had previously shown to enhance temozolomide and topotecan cytotoxicity in adult tumor cell lines [38]. In addition, cells were incubated with medium containing $0.4 \mu \mathrm{M}$ rucaparib, and $0.5-1 \mathrm{~h}$ later 
exposed to varying doses of ionizing radiation (Gulmay Medical RS320 Irradiation System, Gulmay Medical Limited, Surrey, UK). Controls were 0.5\% DMSO or $0.4 \mu \mathrm{M}$ rucaparib alone as appropriate. Cells were harvested by trypsinisation $72 \mathrm{~h}$ later and counted using a CoulterCounter (Beckman coulter UK Ltd.). Cell growth as a percentage of the DMSO or rucaparib alone controls was plotted using GraphPad Prism software (Version 6, GraphPad Software, La Jolla, USA). Concentrations of cytotoxic drugs alone or in combination with rucaparib that inhibited growth by $50 \%\left(\mathrm{GI}_{50}\right)$ were calculated using GraphPad Prism software.

\section{Cell survival/cytotoxicity assays}

Cell survival was determined by colony formation assays using one of 3 different procedures as follows: i) standard assay: exponentially growing cells were seeded onto 6-well plates or 6-cm petri dishes and $24 \mathrm{~h}$ later cells were exposed to drugs (temozolomide, camptothecin, doxorubicin, etoposide) with or without rucaparib $(0.4 \mu \mathrm{M})$ or NU7441 $(1.0 \mu \mathrm{M})$ or the inhibitor alone for $24 \mathrm{~h}(0.4-$ $50 \mu \mathrm{M})$, or exposed to ionizing radiation $(2.69 \mathrm{~Gy} / \mathrm{min}$ at 230 kV, 10 mA, Gulmay Medical Ltd., Surrey, UK), in the presence or absence of rucaparib $(0.4 \mu \mathrm{M})$ or NU7441 $(1.0 \mu \mathrm{M})$, and incubated for a further $24 \mathrm{~h}+/-$ rucaparib/ NU7441 as indicated. Cells were then harvested and reseeded for colony formation in $10 \mathrm{~cm}$ dishes as previously described [23]. Cells treated with medium containing $0.5 \%$ (v/v) DMSO or inhibitor only (rucaparib $0.4 \mu \mathrm{M}$, NU7441 $1.0 \mu \mathrm{M})$ were used as controls. ii) Cells were plated at low densities (50-1000) into 6-well dishes, and without harvesting or reseeding were either exposed continuously to different concentrations of rucaparib $(0.04-50 \mu \mathrm{M})$ for the duration of the experiment (with the addition of fresh drug every 3-5 days); or iii) cells growing in 6-well dishes were exposed to rucaparib $(0.4-50 \mu \mathrm{M})$ for $24 \mathrm{~h}$ followed by drug-free medium for the rest of the experiment. The usual assay performed was the standard assay as in i), only for rucaparib single agent assays were additional experiments (i.e. ii and iii) performed.

After $12-14$ days at $37^{\circ} \mathrm{C}$, colonies were stained with $0.4 \%(\mathrm{w} / \mathrm{v})$ crystal violet and counted using an automated colony counter (ColCount, Oxford Optronics Ltd., Oxford, UK). As the VH-64 cells did not form satisfactory colonies on standard collagen-coated dishes, they were seeded into $6-\mathrm{cm}$ Petri dishes containing a $0.16 \%(\mathrm{w} / \mathrm{v})$ agarose-medium mixture (SeaKem ME Agarose, Lonza, Cologne, Germany) and stained after incubation for 12 days using $0.5 \mathrm{mg} / \mathrm{ml}$ MTT (Sigma, $\mathrm{UK})$ for $2-5 \mathrm{~h}$ at $37^{\circ} \mathrm{C}$. The cloning efficiency (\%) was calculated as [(number of colonies counted/number of cells seeded $\times 100$ ] and cell survival/colony formation $(\%)$ was calculated as [(drug-treated cell cloning efficiency/ control cell cloning efficiency) $\times 100$ ]. The concentration of drug necessary to inhibit colony formation by $50 \%$
$\left(\mathrm{LD}_{50}\right)$ was calculated, and the ratios of $\mathrm{LD}_{50}$ results for the cells treated with cytotoxic alone and the corresponding cells treated with cytotoxic plus inhibitor gave the dimensionless dose reduction factor ${ }_{50}\left(\mathrm{DRF}_{50}\right)$. Cells were plated in triplicates for each drug concentration and each chemo- or radio-potentiation experiment was repeated at least 2 times.

\section{Western blotting}

Western blots for PARP1 were performed using the anti-PARP1 C2-10 primary antibody (Trevigen, MD, USA), as described previously [21].

To measure DNA-PK activity and its inhibition as well as total cellular DNA-PKcs protein levels, cells were either left un-irradiated or exposed to $10 \mathrm{~Gy}$ in the presence or absence of NU7441 $(0.1-5.0 \mu \mathrm{M})$ and protein extraction was performed as previously described [39]. Briefly, after incubating for 30 minutes cellular proteins were extracted in Phosphosafe extraction reagent (Merck, UK), subjected to electrophoresis on 3-8\% (w/w) TrisAcetate XT-Criterion Gels (Biorad, UK), transferred onto nitrocellulose membranes (Hybond C, Amersham Biosciences, UK) and probed with mouse monoclonal DNA-PKcs (ab1832, Abcam, Cambridge, UK), rabbit polyclonal anti-pSer2056 DNA-PKcs (ab18192, Abcam, Cambridge, UK) and anti-Actin (Ab-1) mouse monoclonal antibody (JLA20) (Calbiochem, Nottingham, UK). Following exposure to HRP conjugated secondary antibodies and ECL development, expression was measured by chemiluminescence detection (Fuji LAS; Raytek, Sheffield UK).

\section{PARP activity assay}

PARP activity and its inhibition was measured by a GCLP-validated immunoblot assay that has been previously described, both for clinical material and cell cultures [12, 40]. This assay measures poly ADP-ribose (PAR) formation in permeabilised cells following maximal stimulation by blunt ended oligonucleotides, mimicking DNA breaks, in the presence of excess NAD+. PAR formation was measured using anti-PAR $10 \mathrm{H}$ antibody (kind gift from Prof Dr A Burkle, University of Konstanz, Germany) followed by chemiluminescence detection as described above.

\section{Double strand break (DSB) induction and repair}

DSB were counted by measuring phosphorylation of histone $\mathrm{H} 2 \mathrm{AX}(\gamma \mathrm{H} 2 \mathrm{AX})$ by DNA-PK and ATM, leading to the formation of a $\gamma \mathrm{H} 2 \mathrm{AX}$ focus at the site of the lesion [41]. Rucaparib leads to the formation of DSB by inhibiting SSBR [23]. Measurement of nuclear RAD51 focus formation was used as a marker for functional HRR [42]. 
For the combined assay, TC-71, CADO-ES1 or Hep3B cells as an HRR competent positive control cell line were grown on round $22 \mathrm{~mm}$ collagen coated (for TC-71 and CADO-ES1) glass coverslips (BD Biosciences, UK) in standard 6-well plates for at least $24 \mathrm{~h}$. Cells were then exposed to $10 \mu \mathrm{M}$ rucaparib or vehicle control (i.e. DMSO) for $24 \mathrm{~h}$ at $37^{\circ} \mathrm{C}$, washed twice with cold PBS, fixed with ice-cold 4\% paraformaldehyde and probed for $\gamma \mathrm{H} 2 \mathrm{AX}$ and RAD51 using immunofluorescence microscopy with image analysis using ImageJ as previously described $[23,43]$. Foci in 60-289 cells were counted for each cell line and treatment, on average 166 cells per experiment.

\section{Determination of in vivo anticancer activity}

All animal experiments were performed according to current UK Home Office regulations, complying with the 3R principles (Home Office licence number PPL60/3846). Immunocompromised male rag $2^{-/} \gamma \mathrm{c}^{-/-}$mice were used and implanted intrafemorally with $5 \times 10^{5}$ transduced TC-71 cells as previously described [44]. The TC-71 cells had been transduced with a lentiviral vector encoding both enhanced green fluorescent protein (EGFP) and firefly luciferase (fLuc) allowing to image growing tumors with bioluminescent imaging. Animals were randomly assigned to treatment with vehicle control $\left(\mathrm{dH}_{2} \mathrm{O}, 10 \mathrm{ml} / \mathrm{kg}\right.$ i.p. $)$ or with rucaparib $10 \mathrm{mg} / \mathrm{kg}$ i.p. on days $1-5$ on a 7 -day cycle for a duration of 6 cycles. The dose of $10 \mathrm{mg} / \mathrm{kg}$ i.p. daily $\mathrm{x} 5$ for 6 cycles was selected as it had been well tolerated previously and had shown significant delays in tumor growth in a BRCA1 and BRCA2 mutated mouse models [23]. Treatment of mice started on day 9 after intrafemoral injection of tumor cells, followed by weekly bioluminescent imaging as previously described [44].

\section{Statistical analyses}

All graphs were plotted with the help of Graph Pad Prism software and statistical tests (2-way ANOVA) were calculated using GraphPad Prism (version 6.0).

\section{Abbreviations}

ATCC: American Type Culture Collection; BER: Base excision repair; BRCA: Breast Cancer; CLL: Chronic lymphocytic leukemia; DMEM: Dulbecco's Modified Eagle's Medium; DMSO: Dimethylsulfonic acid; DNA: Deoxyribonucleic acid; DNAPK: DNA dependent protein kinase; DNA-PKcs: DNA dependent protein kinase catalytic subunit; $\mathrm{DRF}_{50}$ Dose reduction factor: ratio of two $\mathrm{LD}_{50}$ results (cells treated with cytotoxic alone and corresponding cells treated with cytotoxic plus inhibitor); DSB: DNA-double strand breaks; $\gamma \mathrm{H} 2 \mathrm{AX}$ : phosphorylated histone H2AX; EFS: Event-free survival; e.g.: exempli gratia; EGFP: enhanced green fluorescent protein; ES:
Ewing sarcoma; ESFT: Ewing sarcoma family of tumors; FBS: Fetal bovine serum; fLuc: firefly Luciferase; $\mathrm{GI}_{50}$ Growth inhibitory dose 50: Concentration that inhibits growth by 50\%; Gy: Gray; h: hours; HRP: Horseraddish peroxidase; HRR : Homologous recombination repair; i.e.: id est; i.p.: intra peritoneal; $\mathrm{LD}_{50}$ Lethal dose 50: The concentration of drug necessary to inhibit colony formation by $50 \%$; $\mathrm{nM}$ : nanomolar; $\mathrm{mM}$ : millimolar; $\mu \mathrm{M}$ : micromolar; MTT: 3-(4, 5-Dimethylthiazol-2-yl)2,5-Diphenyltetrazolium Bromide; NAD: Nicotinamideadenine dinucleotide; NHEJ: Non-homologous end joining; PAR: poly ADP-ribose; PARP: poly (ADP-ribose) polymerase; PBS: Phosphate buffered saline; RAD51: DNA repair protein; RP2D: Recommended phase two dose; RPMI: Roswell Park Memorial Institute medium; SD: Standard deviation; SEM: Standard error of mean; SSBR: Single strand break repair; YAC: Yeast artificial chromosome.

\section{Author contributions}

BV, YTS, HB, AS and SW performed experimental work. BV, YTS, HB, AS and SW interpreted data, BV drafted the manuscript, which was reviewed by all authors. DRN and NC helped with data interpretation and supervision of experimental work.

\section{ACKNOWLEDGMENTS}

This work was supported by grants from the Academy of Medical Sciences/Wellcome Trust and the Bone Cancer Research Trust. We want to thank Fiona Harvey for technical support with experiments.

\section{CONFLICTS OF INTEREST}

The authors BV, YTS, HB, AS and SW have no conflict of interest to declare. The senior author (NC) declares that she has received research funding from Pfizer in connection with rucaparib in the past, and DRN has received (AstraZeneca) or is currently in receipt (Astex Pharmaceuticals) of funding to develop DNA PK inhibitors. DRN and NC are named as inventors on the patent describing the discovery of rucaparib and receive remuneration in line with Institutional policy covering Rewards to Inventors.

\section{FUNDING}

This work was supported by grants to BV from the Academy of Medical Sciences/Wellcome Trust and the Bone Cancer Research Trust, and to SW from the Bone Cancer Research Trust. The PARP-inhibitor rucaparib (formerly AG014699) was a gift from Clovis Oncology, Inc., USA, and temozolomide was a gift from Cancer Research UK. 


\section{Editorial note}

This paper has been accepted based in part on peerreview conducted by another journal and the authors' response and revisions as well as expedited peer-review in Oncotarget.

\section{REFERENCES}

1. Balamuth NJ, Womer RB. Ewing's sarcoma. Lancet Oncol. 2010; 11:184-192.

2. Esiashvili N, Goodman M, Marcus RBJ. Changes in incidence and survival of Ewing sarcoma patients over the past 3 decades: surveillance epidemiology and end results data. J Pediatr Hematol Oncol. 2008; 30:425-430.

3. Hogendoorn PC, Athanasou N, Bielack S, De Alava E, Dei Tos AP, Ferrari S, Gelderblom H, Grimer R, Hall KS, Hassan B, Hogendoorn PC, Jurgens H, Paulussen M, et al, ESMO/EUROBONET Working Group. Bone sarcomas: ESMO Clinical Practice Guidelines for diagnosis, treatment and follow-up. Ann Oncol 2010; 21:204-213.

4. Stahl M, Ranft A, Paulussen M, Bölling T, Vieth V, Bielack S, Görtitz I, Braun-Munzinger G, Hardes J, Jürgens H, Dirksen U. Risk of recurrence and survival after relapse in patients with Ewing sarcoma. Pediatr Blood Cancer. 2011; 57:549-553.

5. Lees-Miller SP, Meek K. Repair of DNA double strand breaks by non-homologous end joining. Biochimie. 2003; 85:1161-1173.

6. Curtin NJ. DNA repair dysregulation from cancer driver to therapeutic target. Nat Rev Cancer. 2012; 12:801-817.

7. Van Gent DC, Van Der Burg M. Non-homologous endjoining, a sticky affair. Oncogene. 2007 26:7731-7740.

8. Weterings E, Chen DJ. The endless tale of non-homologous end-joining. Cell Res. 2008; 18:114-124.

9. Zhao Y, Thomas HD, Batey MA, Cowell IG, Richardson CJ, Griffin RJ, Calvert AH, Newell DR, Smith GC, Curtin NJ. Preclinical evaluation of a potent novel DNA-dependent protein kinase inhibitor NU7441. Cancer Res. 2006; 66:5354-5362.

10. Willmore E, Elliott SL, Mainou-Fowler T, Summerfield GP, Jackson GH, O’Neill F, Lowe C, Carter A, Harris R, Pettitt AR, Cano-Soumillac C, Griffin RJ, Cowell IG, et al. DNA-dependent protein kinase is a therapeutic target and an indicator of poor prognosis in B-cell chronic lymphocytic leukemia. Clin Cancer Res. 2008; 14:3984-3992.

11. Daniel RA, Rozanska AL, Mulligan EA, Drew Y, Thomas HD, Castelbuono DJ, Hostomsky Z, Plummer ER, Tweddle DA, Boddy AV, Clifford SC, Curtin NJ. Central nervous system penetration and enhancement of temozolomide activity in childhood medulloblastoma models by poly(ADP-ribose) polymerase inhibitor AG-014699. Br J Cancer. 2010 103:1588-1596.

12. Daniel RA, Rozanska AL, Thomas HD, Mulligan EA, Drew Y, Castelbuono DJ, Hostomsky Z, Plummer ER, Boddy
AV, Tweddle DA, Curtin NJ, Clifford SC. Inhibition of poly(ADP-ribose) polymerase-1 enhances temozolomide and topotecan activity against childhood neuroblastoma. Clin Cancer Res. 2009; 15:1241-1249.

13. Lupo B, Trusolino L. Inhibition of poly(ADP-ribosyl) ation in cancer: old and new paradigms revisited. Biochim Biophys Acta. 2014; 1846:201-215.

14. Vormoor B, Curtin NJ. Poly(ADP-ribose) polymerase inhibitors in Ewing sarcoma. Curr Opin Oncol. 2014; 26:428-433.

15. Plummer R, Jones C, Middleton M, Wilson R, Evans J, Olsen A, Curtin N, Boddy A, McHugh P, Newell D, Harris A, Johnson P, Steinfeldt H, et al. Phase I study of the poly(ADP-ribose) polymerase inhibitor, AG014699, in combination with temozolomide in patients with advanced solid tumors. Clin Cancer Res. 2008; 14:7917-7923.

16. Syed YY. Rucaparib: First Global Approval. Drugs 2017; 77:585-592.

17. Spahn L, Petermann R, Siligan C, Schmid JA, Aryee DN, Kovar H. Interaction of the EWS NH2 terminus with BARD1 links the Ewing's sarcoma gene to a common tumor suppressor pathway. Cancer Res. 2002 2002; 62:4583-4587.

18. Brenner JC, Feng FY, Han S, Patel S, Goyal SV, BouMaroun LM, Liu M, Lonigro R, Prensner JR, Tomlins SA, Chinnaiyan AM. PARP-1 inhibition as a targeted strategy to treat Ewing's sarcoma. Cancer Res. 2012; 72:1608-1613.

19. Soldatenkov VA, Trofimova IN, Rouzaut A, McDermott F, Dritschilo A, Notario V. Differential regulation of the response to DNA damage in Ewing's sarcoma cells by ETS1 and EWS/FLI-1. Oncogene. 2002; 21:2890-2895.

20. Garnett MJ, Edelman EJ, Heidorn SJ, Greenman CD, Dastur A, Lau KW, Greninger P, Thompson IR, Luo X, Soares J, Liu Q, Iorio F, Surdez D, et al. Systematic identification of genomic markers of drug sensitivity in cancer cells. Nature. 2012; 483:570-575.

21. Zaremba T, Thomas HD, Cole M, Coulthard SA, Plummer ER, Curtin NJ. Poly(ADP-ribose) polymerase-1 (PARP1) pharmacogenetics, activity and expression analysis in cancer patients and healthy volunteers. Biochem J. 2011; 436:671-679.

22. Leahy JJ, Golding BT, Griffin RJ, Hardcastle IR, Richardson C, Rigoreau L, Smith GC. Identification of a highly potent and selective DNA-dependent protein kinase (DNA-PK) inhibitor (NU7441) by screening of chromenone libraries. Bioorg Med Chem Lett. 2004; 14:6083-6087.

23. Drew Y, Mulligan EA, Vong WT, Thomas HD, Kahn S, Kyle S, Mukhopadhyay A, Los G, Hostomsky Z, Plummer ER, Edmondson RJ, Curtin NJ. Therapeutic potential of poly(ADP-ribose) polymerase inhibitor AG014699 in human cancers with mutated or methylated BRCA1 or BRCA2. J Natl Cancer Inst. 2011; 103:334-346.

24. Liston DR, Davis M. Clinically Relevant Concentrations of Anticancer Drugs: A Guide for Nonclinical Studies. Clin Cancer Res. 2017; 23:3489-3498. 
25. Murray J, Thomas H, Berry P, Kyle S, Patterson M, Jones C, Los G, Hostomsky Z, Plummer ER, Boddy AV, Curtin NJ. Tumour cell retention of rucaparib, sustained PARP inhibition and efficacy of weekly as well as daily schedules. Br J Cancer. 2014; 110:1977-1984.

26. Norris RE, Adamson PC, Nguyen VT, Fox E. Preclinical evaluation of the PARP inhibitor, olaparib, in combination with cytotoxic chemotherapy in pediatric solid tumors. Pediatr Blood Cancer. 2014; 61:145-150.

27. Smith MA, Reynolds CP, Kang MH, Kolb EA, Gorlick R, Carol H, Lock RB, Keir ST, Maris JM, Billups CA, Lyalin D, Kurmasheva RT, Houghton PJ. Synergistic activity of PARP inhibition by talazoparib (BMN 673) with temozolomide in pediatric cancer models in the pediatric preclinical testing program. Clin Cancer Res. 2015; 21: 819-832.

28. Choy E, Butrynski JE, Harmon DC, Morgan JA, George S, Wagner AJ, D'Adamo D, Cote GM, Flamand Y, Benes CH, Haber DA, Baselga JM, Demetri GD. Phase II study of olaparib in patients with refractory Ewing sarcoma following failure of standard chemotherapy. BMC Cancer. 2014; 14:813.

29. Stewart E, Goshorn R, Bradley C, Griffiths LM, Benavente C, Twarog NR, Miller GM, Caufield W, Freeman BB 3rd, Bahrami A, Pappo A, Wu J, Loh A, et al. Targeting the DNA repair pathway in Ewing sarcoma. Cell Rep. 2014; 9:829-841.

30. Lee HJ, Yoon C, Schmidt B, Park DJ, Zhang AY, Erkizan HV, Toretsky JA, Kirsch DG, Yoon SS. Combining PARP-1 inhibition and radiation in Ewing sarcoma results in lethal DNA damage. Mol Cancer Ther. 2013; 12:2591-2600.

31. Cavazzana AO, Miser JS, Jefferson J, Triche TJ. Experimental evidence for a neural origin of Ewing's sarcoma of bone. Am J Pathol. 1987; 127:507-518.

32. van Valen F, Winkelmann W, Jürgens H. Type I and type II insulin-like growth factor receptors and their function in human Ewing's sarcoma cells. J Cancer Res Clin Oncol. 1992; 118:269-275.

33. van Valen F. Ewing's sarcoma family of tumors. Human Cell Culture, J. R. W. Masters and B. O. Palsson, Eds. Kluwer Academic Publishers, London. 1999; 1:55-85.

34. Kodama K, Doi O, Higashiyama M, Yokouchi H, Tateishi R, Mori Y. Differentiation of a Ewing's sarcoma cell line towards neural and mesenchymal cell lineages. Jpn J Cancer Res 1994; 85:335-338.

35. Schaefer KL, Eisenacher M, Braun Y, Brachwitz K, Wai DH, Dirksen U, Lanvers-Kaminsky C, Juergens H, Herrero D, Stegmaier S, Koscielniak E, Eggert A, Nathrath M, et al. Microarray analysis of Ewing's sarcoma family of tumours reveals characteristic gene expression signatures associated with metastasis and resistance to chemotherapy. Eur $\mathrm{J}$ Cancer. 2008; 44:699-709.

36. Goggins M, Schutte M, Lu J, Moskaluk CA, Weinstein CL, Petersen GM, Yeo CJ, Jackson CE, Lynch HT, Hruban RH,
Kern SE. Germline BRCA2 gene mutations in patients with apparently sporadic pancreatic carcinomas. Cancer Res. 1996; 56:5360-5364.

37. Cornell L, Munck JM, Alsinet C, Villanueva A, Ogle L, Willoughby CE, Televantou D, Thomas HD, Jackson J, Burt AD, Newell D, Rose J, Manas DM, et al. DNAPK-A Candidate Driver of Hepatocarcinogenesis and Tissue Biomarker That Predicts Response to Treatment and Survival. Clin Cancer Res. 2015; 21:925-933.

38. Thomas HD, Calabrese CR, Batey MA, Canan S, Hostomsky Z, Kyle S, Maegley KA, Newell DR, Skalitzky D, Wang LZ, Webber SE, Curtin NJ. Preclinical selection of a novel poly(ADP-ribose) polymerase inhibitor for clinical trial. Mol Cancer Ther. 2007; 6:945-956.

39. Munck JM, Batey MA, Zhao Y, Jenkins H, Richardson CJ, Cano C, Tavecchio M, Barbeau J, Bardos J, Cornell L, Griffin RJ, Menear K, Slade A, et al. Chemosensitization of cancer cells by KU-0060648, a dual inhibitor of DNA-PK, PI-3K. Mol Cancer Ther. 2012; 11:1789-1798.

40. Plummer ER, Middleton MR, Jones C, Olsen A, Hickson I, McHugh P, Margison GP, McGown G, Thorncroft M, Watson AJ, Boddy AV, Calvert AH, Harris AL, et al. Temozolomide pharmacodynamics in patients with metastatic melanoma: dna damage and activity of repair enzymes O6-alkylguanine alkyltransferase and poly(ADPribose) polymerase-1. Clin Cancer Res. 2005; 11: 3402-3409.

41. Banath JP, Olive PL. Expression of phosphorylated histone $\mathrm{H} 2 \mathrm{AX}$ as a surrogate of cell killing by drugs that create DNA double-strand breaks. Cancer Res. 2003; 63: 4347-4350.

42. Mukhopadhyay A, Elattar A, Cerbinskaite A, Wilkinson SJ, Drew Y, Kyle S, Los G, Hostomsky Z, Edmondson RJ, Curtin NJ. Development of a functional assay for homologous recombination status in primary cultures of epithelial ovarian tumor and correlation with sensitivity to poly(ADP-ribose) polymerase inhibitors. Clin Cancer Res. 2010; 16:2344-2351.

43. Patterson MJ, Sutton RE, Forrest I, Sharrock R, Lane M, Kaufmann A, O’Donnell R, Edmondson RJ, Wilson BT, Curtin NJ. Assessing the function of homologous recombination DNA repair in malignant pleural effusion (MPE) samples. Br J Cancer. 2014; 111:94-100.

44. Vormoor B, Knizia HK, Batey MA, Almeida GS, Wilson I, Dildey P, Sharma A, Blair H, Hide IG, Heidenreich O, Vormoor J, Maxwell RJ, Bacon CM. Development of a preclinical orthotopic xenograft model of ewing sarcoma and other human malignant bone disease using advanced in vivo imaging. PloS one. 2014; 9:e85128. https://doi. org/85110.81371/journal.pone.0085128. 